
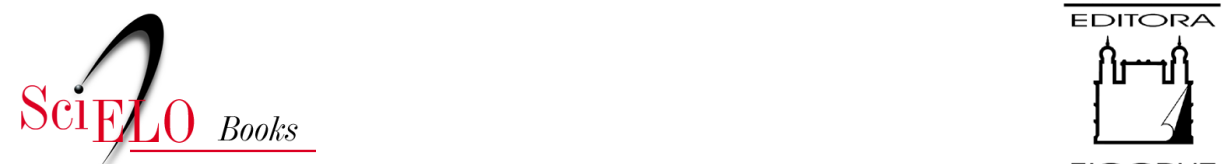

FIOCRUZ

\title{
5. Agricultura e genes
}

\author{
Eloi S. Garcia
}

\section{SciELO Books / SciELO Livros / SciELO Libros}

GARCIA, E.S. Agricultura e genes. In: Genes: fatos e fantasias [online]. Rio de Janeiro: Editora FIOCRUZ, 2006, pp. 107-116. ISBN: 978-65-5708102-0. https://doi.org/10.7476/9786557081020.0007.

\section{(c) ()

All the contents of this work, except where otherwise noted, is licensed under a Creative Commons Attribution 4.0 International license.

Todo o conteúdo deste trabalho, exceto quando houver ressalva, é publicado sob a licença Creative Commons Atribição 4.0.

Todo el contenido de esta obra, excepto donde se indique lo contrario, está bajo licencia de la licencia Creative Commons Reconocimento 4.0. 


\section{5 \\ Agricultura e Genes}

Atualmente estamos entrando em uma nova era da agricultura com um papel central da biologia molecular, devido ao enorme avanço nos conhecimentos básicos da biologia vegetal e a aplicação de técnicas de engenharia genética. Esta revoluçāo vai depender menos das inovaçōes mecânicas ou químicas e mais do uso intensivo do saber científico e técnicas moleculares e celulares. As promessas da biotecnologia agrícola focalizam a produtividade, a redução de custos, a geraçāo de inovações e melhorias nos alimentos e o estabelecimento de práticas agrícolas mais ecológicas. Nunca houve tanta aplicação prática da ciência como na área agrícola.

\section{Biodiversidade e Riqueza}

A maior parte de aproximadamente 30 milhões de espécies de plantas, animais, bactérias, fungos e virus que existem no nosso planeta encontra-se nas florestas tropicais. Na floresta Amazônica, por exemplo, 15.000 espécies de animais foram catalogadas, oito mil das quais consideradas novas quando descobertas. Quarenta por cento dos peixes de água doce, $25 \%$ das espécies de pássaros e 5.000 espécies de árvores conhecidas no planeta são encontradas na Amazônia.

O número de microorganismos encontrados no solo é enorme. Utilizando-se marcadores de DNA, estima-se que em um grama de solo da floresta nativa sejam encontradas mais de duas mil espécies de microorganismos. Imaginem os milhares de novos genomas e proteomas que serão descobertos nesta diversidade biológica! Estimem o número de genes inéditos que serão conhecidos em nossa biodiversidade! Entretanto, o desflorestamento diminui enormemente o número e as espécies de bactérias c fungos, além de alterar várias propriedades do solo, como o $\mathrm{pH}$, elementos químicos, densidade e porosidade. 
Desde que as técnicas de biologia molecular tornaram-se disponiveis, avalanches de descobertas estão sendo divulgadas relacionando a biodiversidade com saúde, principalmente na área dos fármacos. Este desenvolvimento científico levará a mais do que uma revolução na área médica, pois se refletirá na economia, na política e na qualidade de vida do ser humano. Novos medicamentos desenvolvidos com base na biodiversidade serão utilizados para tratamento de doenças intratáveis ou tidas como de difícil terapia. Novas formas de aplicaçāo de drogas estão sendo inovadas. Em breve, ao usar sabonetes, pastas de dente, cosméticos, aerossóis e alimentos, uma pessoa poderá estar tomando sua dose diária de medicamentos. Nos últimos 10 anos, 60\% das drogas novas usadas no tratamento de câncer foram descobertas nas florestas tropicais. $\mathrm{O}$ mercado mundial de medicamentos derivados de plantas é de 200 bilhões de dólares/ano.

Apesar dos esforços realizados pelas universidades e institutos de pesquisa nacionais, a diversidade biológica brasileira ainda é pouco investigada. Verdadeiras barreiras restritivas à pesquisa e inovação nesta área são as leis rígidas e verticalizadas vigentes na burocracia pública. É importante concentrar o debate no que é factivel e não em fantasias. Os avanços do conhecimento impõem a necessidade urgente de mudanças destas normas. É importante traçar leis flexíveis para determinar, deliberar e facilitar a investigaçāo com material biológico, bem como a cooperação nacional e internacional.

Já é hora de encarar os receios e as vantagens do estudo da biodiversidade. Inexplorada e desconhecida, ela tem valor zero para a sociedade, pois não gera empregos nem riquezas. Não resta dúvida de que é necessário prevenir possíveis abusos. No entanto, dificultar e burocratizar a investigaçāo científica tira o ânimo e a competitividade de nosso país e não resolve o problema. Afinal, quantas espécies de microorganismos podem estar saindo no barro ou na poeira aderida nos tênis de nossos turistas?

\section{Biotecnologia Agricola}

Não resta dúvida que o mundo está crescendo. A população hoje é de aproximadamente seis bilhões de pessoas. As estimativas demonstram que ela será nove bilhōes em 2050. Isso significa uma população crescendo na base de 78 milhōes por ano e que cerca de $20 \%$ deste crescimento demográfico estará na Índia, 50 milhões de pessoas aumentará na Ásia, 18 milhões na África e 8 milhões na América Latina e no Caribe. O restante deste crescimento estará em países estáveis, como os Estados Unidos e Europa. Mais do que isto, 
enquanto a economia dos países ocidentais crescerá aproximadamente $2 \%$, a China vai crescer mais do que $8 \%$ e a Índia em torno de $5 \%$. Isto significa que a população destes países terá mais dinheiro para o consumo. Por outro lado, os países em desenvolvimento estão se urbanizando, o que induzirá a diminuiçāo dos produtores e o aumento dos consumidores. Para onde isto poderá direcionar o mundo?

O passo lógico será um aumento da produção agrícola. A biotecnologia pode oferecer aos agricultores uma maneira mais elaborada de produzir cultivares. Os principais benefícios da biotecnologia agrícola incluem resistência a doenças e pragas, reduçāo do uso de pesticidas, frutas e grãos com composição mais nutritiva, tolerância a herbicidas, mais rápido desenvolvimento dos vegetais e melhoria do sabor e qualidade do alimento. As plantas são manipuladas geneticamente (GM) de maneira mais fácil do que animais. Assim, o avanço nesta tecnologia aplicada a plantas será mais rápido do que para animais. $O$ solo para cultivo está limitado devido aos ambientalistas. A biotecnologia poderá melhorar a eficiência da seleção natural de plantas e aumentar a produtividade agrícola. Nos próximos cinco anos os alimentos transgênicos comerciais terão seus genomas conhecidos. Estes produtos utilizarão menos fertilizantes, crescerāo em terrenos ácidos e áridos e produzirāo mais do que uma planta comum.

O suplemento de alimento deve crescer no mundo. Para continuar este aumento utilizando-se da agricultura tradicional, teríamos necessidade de plantar em mais 10 milhões de hectares. Isto seria uma catástrofe para o ecossistema. Ou seja, isto significaria mais desmatamento com drásticas conseqüências para - meio ambiente. O suprimento de alimento deve dobrar nos próximos 30 anos. No entanto, $80 \%$ da futura produçāo de alimentos deve continuar sendo em terras utilizadas hoje, ou seja, haverá limitação para expansão de solos produtivos. Um dos maiores problemas será na África que terá um solo com diminuição da fertilidade, difícil aplicação da melhoria tecnológica, isolamento rural devido à falta de estradas e transportes, bem como educação deficiente e falta de serviço de saúde.

Em 2003, as plantaçōes GMs foram cultivadas em mais de 70 milhões de hectares de 18 países, o que representa uma área duas vezes maior que a Inglaterra. Aproximadamente cinco milhōes de pequenos agricultores no Brasil, China, Índia, África do Sul e México estão plantando algodão GM resistente a pragas. Calcula-se uma economia de cerca de US $\$ 500$ por hectare, principalmente através uma redução de $70 \%$ no uso de pesticidas. O cultivo de plantas GMs está crescendo no mundo todo e já é bastante difundido nos EUA, Canadá e 
Argentina, mas somente agora está sendo liberado em alguns países da Europa, pois ainda existe receio quanto à ameaça que ele representa para o meio ambiente e a saúde humana e animal.

As maiores contribuiçōes dos vegetais GMs ainda estão para chegar. Uma delas, provavelmente, será a reduçāo drástica do uso de agrotóxicos. Este é o caso das variedades de feijão e mamão resistentes a doenças viróticas, ou da melhora do milho e do algodão resistentes a lagartas. No Brasil, a Empresa Brasileira de Pesquisa Agropecuária (Embrapa) investiu muito nesta tecnologia e desenvolveu inúmeros tipos de plantas modificadas. China, Cuba e Índia avançam velozmente nas plantas transgênicas. A investigação de plantas geneticamente alteradas trará benefícios para a saúde pública. Algumas vantagens já foram obtidas somente pela redução do uso de inseticidas.

Maiores benefícios virão com o desenvolvimento de vacinas, anticorpos e outras proteínas medicamentosas. Vacinas contra hepatite $B$, bactérias e vírus que causam diarréias foram desenvolvidas em batatas e bananas e estão sendo testadas. Possivelmente para fins comerciais estas vacinas serāo produzidas em bananas, alface ou em suco de tomate, para serem ingeridas. Uma das vantagens é que estes produtos não serão administrados por injeção e estarão livres de possíveis contaminaçōes por agentes patogênicos humanos. Estas vantagens devem ser mais discutidas pela mídia e ignorá-las não é uma opção.

Os principais produtos melhorados pelo uso da biotecnologia foram o milho, a soja e as batatas que necessitam de menor aplicação de pesticidas/herbicidas; a soja com menor teor de lipídeo saturado, mais ácido oléico e maior estabilidade à oxidação; o mamão papaya resistente a vírus; o arroz que cresce mais rápido, mais rico em proteínas e capaz de tolerar melhor o solo ácido; a batata e o milho resistentes a doenças e com produção aumentada; entre outros. A produçāo de novas variedades de cultivares pela biotecnologia continua.

Veja um belo exemplo do que pode ser a agricultura nos próximos anos. O ser humano e o trigo caminham juntos pelo planeta pelo menos há 10.000 anos, adaptando-se a climas e solos diferentes. $O$ homem tornou-se dependente do trigo, que é cultivado em mais de 70 países. Utilizando-se deste cereal foram descritos recentemente genes que dão habilidade ao trigo de crescer em diferentes climas, permitindo a esta planta sobreviver em condiçōes extremas. Os dois genes revelados foram o VRN, que ativa a florescência, e o VRN2, que atrasa este processo, permitindo ao trigo desenvolver-se desde regiōes de longo inverno até áreas temperadas e tropicais. 
Os benefícios esperados num futuro próximo são as reduçōes dos níveis de toxinas naturais em plantas, a obtenção de métodos mais específicos, simples e rápidos para localização de um agente patogênico, toxinas e contaminantes e o aumento do tempo de exposição nas prateleiras dos supermercados sem os produtos estragarem. Os principais produtos já desenvolvidos para o mercado incluem o óleo de soja e de canola contendo mais estearato, podendo-se produzir margarinas mais saudáveis, melōes menores e sem sementes, bananas e abacaxis com menor tempo de maturaçāo, ervilhas de crescimento mais rápido e em maior quantidade, amendoim com mais proteínas e bananas resistentes a fungos. Ainda poderemos ter tomates com maior concentração de antioxidante (licopeno); batatas com maior conteúdo sólido (amido), o que reduz a quantidade de óleo absorvido durante a fritura; frutas e verduras com maiores teores de vitaminas, como a $\mathrm{C}$ e a $\mathrm{E}$; alho que produz mais alicina, possivelmente socorrendo na redução dos níveis de colesterol; arroz com maior teor de proteínas, utilizando genes obtidos de ervilhas; cerejas com maior nível de ácido elágico, um agente anticancerígeno natural, entre outros.

A população mundial deverá dobrar, ou seja, o planeta terá aproximadamente 10 bilhōes de pessoas até 2050 . Poucas outras tecnologias serāo capazes de oferecer as mesmas vantagens da biotecnologia, com o potencial de socorrer e evitar a fome no próximo século. Solos áridos e ácidos poderão ser utilizados para agricultura com a mesma eficiência de um solo fértil. Isto certamente aumentará a economia dos países em desenvolvimento, gerando mais empregos e maior produtividade.

Alguns acreditam que a ciência está planejando a natureza melhor do que a própria natureza. Entretanto, os impactos e as implicaçōes desta tecnologia ainda não são completamente compreendidos. A discussão do momento é sobre os riscos e benefícios possiveis dos organismos geneticamente modificados (OGMs), sob o ponto de vista de uma ciência ambientalista e ecológica. Ou seja, como os OGMs devem ser desenvolvidos e regulados levando em conta a perspectiva científica, política, socioeconômica, moral e ética.

Um monitoramento bem planejado é crucial para identificar os riscos de um OGM no ambiente, principalmente quando há razão de suspeita de um problema possível. Em alguns casos, quando uma planta GM é cultivada, este monitoramento detecta riscos ao ambiente que não eram evidentes em pequena escala. Ecologistas e ambientalistas do mundo todo, a princípio, fazem oposição radical aos OGMs, principalmente às plantas geneticamente manipuladas. 
É difícil entender esta posição. Oposição radical contra alimentos transgênicos é o triunfo do dogma sobre a razão. Ou da esquerda sobre a direita. Ora, os transgênicos servem tanto para o capitalismo quanto para o socialismo. É melhor nāo entrar neste véu ideológico.

Por que não fazem campanha contra os medicamentos e vacinas produzidas por modificação genética? A mesma tecnologia utilizada para inserir um gene humano na levedura a fim de produzir insulina para indivíduos diabéticos é usada para modificar uma plantação GM. Qual a razão de uma técnica poder ser usada para produção de medicamentos, mas não poder modificar vegetais tornando-os resistentes a pragas? Porque existe esta reaçāo gigantesca dos ativistas verdes contra a modificaçāo genética de plantas?

Devido à comercialização de plantas GM ser relativamente recente e limitada somente a poucos tipos de vegetais muitas das questões levantadas necessitam de um estudo mais profundo, pois somente foram analisadas empiricamente. Mas os riscos dos OGMs são mais conhecidos entre os ecologistas, as agências reguladoras e o público, enquanto os benefícios ao meio ambiente necessitam ainda serem pesquisados e documentados com mais rigor científico.

Por centenas de anos as plantas têm sido usadas para tratamentos e terapias de inúmeras doenças. Com o avanço da biotecnologia, as plantas estāo começando a serem utilizadas com 'fábricas' produtoras de proteínas terapêuticas que servirão de matéria-prima para formulação de medicamentos. Plantas produtoras de drogas são resultados de uma aplicação alternativa da biotecnologia. Esta metodologia é de baixo custo, segura e mais eficiente se comparada aos tradicionais processos utilizando fermentaçāo microbiana ou culturas de células animais. Uma outra vantagem é de que as plantas não propagam agentes patogênicos que podem infectar o ser humano ou outros animais.

Comparado com outros métodos existentes, a planta tem mais habilidade para assimilar a informação genética e produzir proteínas complexas que podem ser usadas na formulação de remédios mais efetivos. Os métodos de culturas de células são caros e trabalhosos e não produzem a quantidade suficiente de proteínas terapêuticas para atender as necessidades do mercado. Em muitos casos, o custo de produção de uma proteina medicamentosa é significativamente barato porque não necessita tanto de investimentos como nos métodos tradicionais de produção. 
A humanidade vem modificando plantas no nível genético desde o seu primórdio. O destino da sociedade humana, bem como da agricultura, tem sido mutuamente vinculado $\mathrm{e}$ dependente desde então. A agricultura permitiu ao ser humano deixar de ser somente caçador para construir seu desenvolvimento econômico e cultural. Nossos ancestrais escolheram umas poucas plantas selvagens e, gradualmente, as modificaram pela seleção das maiores, mais saborosas e mais resistentes, para então propagá-las. Assim, organismos têm sido alterados por milênios, nos trazendo arroz, trigo, milho, soja, batata e tomates que têm poucas semelhanças com seus ancestrais. Por exemplo, o tomate e a batata continham potentes toxinas. Hoje, variedades destas plantas têm sido cultivadas, produzindo alimentos saudáveis e nutritivos.

A maioria das plantaçōes não é natural por apresentar diferenças com seus ancestrais selvagens e, também, devido à sua origem e domesticação ter ocorrido em locais diferentes dos de sua origem. Por exemplo, o Brasil produz milho e soja que sāo variedades nativas do México e da China, respectivamente. O trigo foi domesticado na Mesopotâmia, o café tem origem na Etiópia, a laranja na Índia, a cana de açúcar em Papua Nova Guiné, a batata na Europa, a mandioca na África, a batata doce no Japāo. Um exemplo de modificaçāo genética foi revelado num estudo recente, onde os pesquisadores compararam genes de milho recuperados no México e nos Estados Unidos, e descobriram que três variantes genéticas foram sistematicamente melhoradas, provavelmente através de cultivos seletivos, por centenas e centenas de anos, pelos fazendeiros primitivos. A planta ancestral do milho, o teosinto, foi domesticada entre 6.000 e 9.000 anos atrás no México. Esta planta, considerada somente uma semente, ainda é encontrada no país. Pelo cultivo e seleçāo das características desejáveis, os agricultores daquele tempo causaram, no teosinto, mudanças fantásticas visando ao aumento da produção de alimento.

Há cerca de 5.500 anos o tamanho dos poucos grãos de milho na espiga era maior. Entretanto, todas as variantes genéticas já eram encontradas no milho 'moderno' que crescia no México há 4.400 anos. A planta foi tão modificada pelo cultivo direto que evoluiu para uma forma que não podia se desenvolver e dependia dos agricultores para sobreviver nas consecutivas gerações. Hoje, o México possui 59 espécies de milho. Os pesquisadores acreditam que dificilmente estas modificaçōes genéticas tenham sido realizadas de maneira 
espontânea. Aparentemente, os agricultores primitivos eram muito mais sofisticados do que imaginávamos. A diferença entre o teosinto e o milho está somente em alguns poucos genes que causam uma enorme mudança. Provavelmente $o$ agricultor primitivo descobriu que, plantando as sementes de um milho de melhor qualidade perto de um outro de pior qualidade, poderia ocasionar trocas benéficas no de pior qualidade nas próximas geraçōes. Caso tivesse encontrado a combinação correta, o fazendeiro ancestral dividia este conhecimento com seus amigos e parentes.

Somente três genes que apareceram num curto espaço de tempo melhoraram, dramaticamente, a qualidade do milho. Um gene mudou a arquitetura da semente. Outro induziu a produção de um grão mais macio, e uma mudança na consistência do milho, facilitando o brotamento da planta. $O$ terceiro gene tornou o grão de sabor mais agradável, pela modificação da concentração de amido. Provavelmente estas mudanças nas características do milho encorajaram os agricultores primitivos a propagarem a planta para outras regiōes.

A agricultura moderna somente se desenvolveu nos primeiros anos de 1700 , quando os cientistas criaram as primeiras plantas híbridas, obtidas pelo cruzamento de dois tipos de plantas diferentes. Na década de 1840, um monge austríaco, Gregório Mendel, trabalhando com ervilhas, definiu as primeiras leis da hereditariedade. Pesquisadores europeus, no início de 1900 , utilizando a técnica desenvolvida por Mendel, começaram a melhorar as plantas existentes. Em 1953, Watson e Crick descobriram a estrutura do DNA. Vinte anos após, foi descoberto como isolar genes. Na década de 1980, a informação genética pôde ser transferida de um organismo para outro. Pela manipulação de genes, os pesquisadores puderam formar novas proteínas que protegem a planta contra doenças. Em 1985, plantas geneticamente modificadas foram testadas no campo. O tomate Flavr Savr, que tem seu processo de maturação retardado, foi liberado para consumo nos EUA em 1994. Logo após, foi desenvolvida a soja resistente a herbicidas. De lá para cá, inúmeras plantas foram alteradas geneticamente.

Como vimos os avanços na genética foram progressivamente rápidos. As aplicações deste conhecimento em processos inovadores estão apenas se iniciando. Os genes transferidos artificialmente para o genoma de um organismo, isto é, os transgenes, permitem a criação de organismos que não podem ser obtidos através de uma reprodução sexual normal. O ser humano tem receio do alimento que come. Mas a civilização foi desenvolvida utilizando plantas geneticamente modificadas pela natureza e pelo homem. A humanidade nāo 
existiria se não fosse esta técnica empiricamente desenvolvida pelo agricultor primitivo há mais de 8.000 anos. Assim, na evolução da espécie, o ser humano se alimentou de plantas geneticamente modificadas pela natureza. Por milhares de anos o arroz, na China, e o milho, no México, por exemplo, foram alterados através do cultivo seletivo. Com efeito, foi praticamente uma revolução verde na pré-história.

Desde então a demanda global por alimento tem levado ao melhoramento dos vegetais. A biotecnologia tem desenvolvido tecnologia para produzir alimentos mais saborosos e nutritivos, com alta produtividade das plantas que são protegidas naturalmente das doenças e pragas. As plantações biotecnológicas estão se tornando significantes componentes da economia de vários países, inclusive do Brasil. A biotecnologia vegetal tem feito o possível para o melhoramento seletivo e hibridização das colheitas. Este processo permite a transferência de somente um ou poucos genes desejáveis, permitindo o desenvolvimento de vegetais benéficos sem problemas indesejáveis. A tecnologia de hoje permite a alteração de uma característica da planta, reduzindo o tempo do desenvolvimento de uma planta melhor. Ao invés de gastar 10 a 12 anos para desenvolver plantas da maneira tradicional, misturando milhares de genes, no sistema moderno seleciona-se um gene específico de qualquer vegetal que é posteriormente colocado no genoma de uma outra planta através da biotecnologia.

Além de ser benéfico em termos de crescimento, proteçāo contra pragas, produtividade e, conseqüentemente, economia, esse método também pode ser saudável para o meio ambiente devido ao fato de as plantações protegidas contra pragas, por exemplo, reduzirem a utilização de pesticidas. A transgênese de plantas também reduz a necessidade de controle de pragas, o tempo e a área cultivada, protegendo o solo. Por séculos, os agricultores têm usado a biologia pela sua vantagem de modificar genes para produzir melhores pães, cervejas, vinhos e queijos. Os processos por eles empregados foram semelhantes aos utilizados pela biotecnologia agrícola atual.

Um belo exemplo está no processo usado para produzir queijos. Num passado ainda recente, a principal enzima envolvida era a renina, extraída do estômago de bovinos. Utilizando a biotecnologia remove-se o gene específico que codifica a renina e se produzem bactérias através do processo de fermentação, eliminando a necessidade da extração do bovino. Atualmente, $50 \%$ da renina usada na fabricação de queijos é produzida por fermentação. O fermento utilizado na fabricação de pães também foi trabalhado pela biotecnologia, resultando numa 
levedura que age mais rapidamente no processo de produzir pães e outras massas. Este fermento tem certos genes rearranjados e duplicados. Os padeiros ancestrais poderiam ter feito a mesma coisa, mas só alcançariam resultados com dezenas de anos de experimentos. 